\title{
FORMULASI TABLET EKSTRAK BUAH NAGA (Hylocereus polyrhizus) MENGUNAKAN AMILUM UBI JALAR PREGELATINASI SEBAGAI BAHAN PENGHANCUR
}

\section{TABLET FORMULATION FROM DRAGON FRUIT EXTRACT (Hylocereus polyrhizus) USING SWEET POTATO PREGELATINIZED STARCH AS DISINTEGRATION}

\author{
Aji Winanta $^{1^{*}}$, Yandi Syukri², Lutfi Chabib ${ }^{2}$ \\ 1. Departemen Fisika Farmasi, Program Studi Farmasi, Fakultas Kedokteran dan \\ Ilmu Kesehatan, Universitas Muhammadiyah Yogyakarta, Jl. Brawijaya, Bantul, \\ Yogyakarta 55183, Indonesia \\ 2. Departemen Teknologi Farmasi, Program Studi Farmasi, Fakultas Matematika dan \\ Ilmu Pengetahuan Alam, Universitas Islam Indonesia, Jl. Kaliurang km 14,5, \\ Sleman, Yogyakarta 55281, Indonesia
}

Submitted : 26 Juli 2018 Reviewed : 14 Februari 2019 Accepted : 16 Maret 2019

\begin{abstract}
ABSTRAK
Buah naga (Hylocereus polyrhizus) telah dikenal oleh masyarakat sebagai tanaman yang kaya akan kandungan antioksidan sehingga mempunyai manfaat sebagai antikanker. Sediaan dari buah naga belum banyak digunakan oleh masyarakat luas, oleh karena itu dibuat suatu formulasi sediaan tablet dari ekstrak buah naga yang dapat dikonsumsi oleh masyarakat sebagai suplemen kesehatan yang dapat dengan praktis dikonsumsi. Tablet ekstrak buah naga dibuat dengan menggunakan amilum pregelatinasi ubi jalar sebagai bahan penghancur. Penelitian ini bertujuan untuk mengetahui pengaruh variasi kadar amilum ubi jalar pregelatinasi (kadar 5\%; 6,5\%; 8\%; dan 10\%) terhadap sifat fisik tablet ekstrak buah naga. Ekstraksi buah naga dilakukan dengan metode maserasi dan proses penabletan menggunakan metode granulasi basah. Hasil yang diperoleh pada formula I mempunyai kekerasan 7,97 Kg, kerapuhan 0,29\%, waktu hancurnya 41,69 menit. Formula II mempunyai kekerasan 6,23 Kg, kerapuhan 0,58\%, waktu hancur 36,43 menit. Formula III memiliki kekerasan 7,65 Kg, kerapuhan 0,46\%, waktu hancur 35,15 menit. Dan pada Formula IV mempunyai kekerasan $7,43 \mathrm{Kg}$, kerapuhan $1,18 \%$ dan waktu hancur 32,03 menit. Kesimpulannya semakin tinggi konsentrasinya akan membuat kekerasan tablet menurun, kerapuhan menjadi semakin besar dan waktu hancur tablet semakin cepat.
\end{abstract}

Kata kunci : ekstrak buah naga (Hylocereus polyrhizus), amilum pregelatinasi ubi jalar, bahan penghancur. 


\begin{abstract}
Dragon fruit (Hylocereus polyrhizus) has been recognized by society as a plant rich in antioxidants that has benefits as anticancer. Dosage form of the dragon fruit has not been used widely by the public, therefore was made a tablet formulation from dragon fruit extract that can be consumed by the public as a health supplement that can conveniently be consumed. The tablet from dragon fruit extract made using sweet potato pregelatinized starch as disintegrant. This study aimed to determine the influence of variations starch content of sweet potato pregelatinized starch (levels 5\%,6.5\%,8\%, and 10\%) of the physical properties tablet. Dragon fruit extraction method was used for maceration and tablet process using wet granulation methods. The result is formula I has a hardness $7.97 \mathrm{Kg}$, friability $0.29 \%$, disintegration time 41.69 minutes. Formula II has a hardness $6.23 \mathrm{Kg}$, friability $0.58 \%$, disintegration time 36.43 minutes. Formula III has a hardness $7.65 \mathrm{Kg}$, friability $0.46 \%$, disintegration time 35,15 minutes. And in Formula IV has a hardness $7.43 \mathrm{Kg}$, friability $1.18 \%$, disintegration time 32.03 minutes. The conclusion was higher levels sweet potato pregelatinized starch is will make the tablet hardness decline, high friabilty and accelerate the disintegration time.
\end{abstract}

Keywords: dragon fruit (Hylocereus polyrhizus) extract, sweet potato pregelatinized starch, disintegrant

\title{
Penulis korespondensi:
}

Aji Winanta

Departemen Fisika Farmasi, Program Studi Farmasi, Fakultas Kedokteran dan Ilmu Kesehatan, Universitas Muhammadiyah Yogyakarta

Jl. Brawijaya, Bantul, Yogyakarta 55183, Indonesia

e-mail: a.winanta@gmail.com/ 082221556698

\section{PENDAHULUAN}

Buah naga (Hylocereus polyrhizus) merupakan tanaman yang berasal dari Meksiko dan tumbuhan ini dapat tumbuh dengan baik di Indonesia. Buah naga (Hylocereus polyrhizus) mengandung senyawa seperti air, betakaroten, serat, kalsium, fosfor, besi, vitamin B1, vitamin B2, Vitamin C, Niasin (Anonim, 2005). Buah ini memiliki kandungan serat, vitamin $\mathrm{C}$, mineral dan fitoalbumin yang sangat tinggi, dimana bahan - bahan memiliki khasiat sebagai antioksidan (Jaafar et al., 2009). Hasil penelitian Nurliyana dkk. menunjukkan bahwa ekstrak buah naga (Hylocereus polyrhizus) terbukti mempunyai aktivitas sebagai antioksidan /penangkap radikal karena memiliki kandungan betacyanin yang tinggi dan juga kaya akan senyawa fenolik (Nurliyana dkk.,2010). Penelitian yang lain juga menunjukan bahwa buah naga merah mempunyai aktifitas antioksidan dan antiproliferatif sehingga mampu menghambat sel tumor (Li-chen et al., 2006).

Buah naga (Hylocereus polyrhizus) digunakan dengan cara dikonsumsi secara langsung dalam bentuk buah segar atau juga penyajian buah naga dapat berupa jus, es krim, sari buah, manisan maupun selai. Hal tersebut kurang praktis digunakan sehingga perlu dibuat sediaan ekstrak buah naga (Hylocereus polyrhizus) yang lebih praktis digunakan yaitu tablet.

Formulasi dan pembuatan tablet dari ekstrak buah naga (Hylocereus polyrhizus) dilakukan secara granulasi basah dengan variasi kadar penghancur amilum ubi jalar pregelatinasi. Amilum pregelatinasi mempunyai kemampuan mengembang yang besar, dimana setelah adanya penyerapan oleh tablet amilum pregelatinasi akan cepat mengembang sehingga mengakibatkan pecahnya tablet. Selain faktor keberadaan bahan penghancur dalam formulasi, perbedaan kadarnya juga dapat berpengaruh terhadap kekerasan, kerapuhan dan 
waktu hancur tablet. Kenaikan konsentrasi bahan penghancur akan mempercepat waktu hancur tablet setelah kontak dengan cairan pencernaan (Sulaiman, 2007). Telah dilakukan sebelumnya studi tentang pengaruh suhu terhadap karakterisasi fisikomekanik amilum ubi jalar sebagai alternatif untuk bahan tambahan dalam formulasi tablet, namun belum dikembangkan pada pembuatan tablet. Dari hasil penelitian tersebut diketahui bahwa amilum pregelatinasi ubi jalar dengan suhu pemanasan $80^{\circ} \mathrm{C}$ mempunyai sifat yang baik sebagai bahan penghancur (Adibah, 2010). Penelitian ini dilakukan untuk mengetahui sifat fisik tablet ekstrak buah naga (Hylocereus polyrhizus ) dengan menggunkan amilum yang terdapat dalam ubi jalar yang terpregelatinasi yang dapat dimanfaatkan sebagai eksipien dalam formulasi sediaan tablet.

\section{METODE PENELITAN}

\section{Alat dan Bahan}

Alat yang digunakan dalam penelitian ini adalah mesin penggiling, kertas saring, aluminium foil, rotary evaporator (Heidolp), alat-alat gelas, ayakan mesh 12,16, 40; alat penyaring, corong stainless steel, mortir, stemper, lemari pengering, termometer, viscometer Brookfield, neraca analitik tipe Dragon 204 (Mettler Toledo), mesin tablet single punch (Korsh EK0), hardness tester (Vanguard), waterbath (Memmert), friability tester (Erweka / TA-100), disintegration tester (Erweka ZT 502). Alat - alat yang digunakan dalam uji KLT (Kromatografi Lapis Tipis) adalah silika gel $\mathrm{F}_{254}$, silika gel $60 \mathrm{~F}_{254}$ dan selulosa.

Bahan yang digunakan dalam penelitian ini adalah buah naga yang diperoleh dari kebun Sabila, kecamatan Pakem, kabupaten Sleman, Yogyakarta dan ubi jalar yang diperoleh dari kecamatan muntilan kabupaten Magelang, aerosil (kualitas farmasi), laktosa (DMV-Fonterra), mucilago amilly, amilum pregelatinasi ubi jalar, magnesium stearat (peter greven), talkum (kualitas farmasi), metanol 80\%, metanol - amonia (100:1,5), Etil Asetat Asam Asetat - Asam Formiat - Air (100:11:11:27), metanol - asam formiat 10\% (95:5) (fase gerak), pereaksi Dragendrof, uap amoniak dan ferri chloride.

\section{Tahapan Penelitian}

\section{Determinasi tanaman buah naga}

Tanaman buah naga yang digunakan dalam penelitian terlebih dahulu dideterminasi untuk memastikan jenis spesies tanaman tersebut. Determinasi dilakukan oleh peneliti di Laboratorium Biologi Farmasi Universitas Islam Indonesia dengan menggunakan buku panduan yaitu Flora dan Flora of Java.

\section{Pembuatan Ekstrak Buah naga}

Buah naga dicuci dibawah air yang mengalir kemudian dikupas untuk memisahkan kulit dari daging buahnya. Daging buah yang dapat dimakan dipotong kecil - kecil $(1,5 \mathrm{~cm} \times 1,5 \mathrm{~cm}$ x 1,5 cm) kemudian dikeringkan dalam lemari pengering sampai kering (selama 5 hari), setelah itu dihaluskan menggunakan blender selama 1 menit. Serbuk kering yang di dapat kemudian di maserasi di dalam bejana dengan menggunakan metanol 80\% selama 5 hari. Ekstrak metanol yang diperoleh kemudian dipekatkan dengan menggunakan rotary evaporator pada suhu $40^{\circ} \mathrm{C}$ sampai didapatkan ekstrak kental (Rebecca, 2010). Ekstrak yang diperoleh kemudian diserbukan secara manual dengan penambahan aerosil.

\section{Pemeriksaan Kualitas Ekstrak}

Uji pemeriksaan kualias ekstrak meliputi:

a. Pemeriksaan karakteristik ekstrak buah naga

Uji karakteristik ekstrak buah naga meliputi uji organoleptik. Kadar air, kekentalan.

1) Uji organoleptik 
Dilakukan pemeriksaan untuk mendiskripsikan bentuk, warna, bau dan rasa dari ekstrak.

2) Uji kadar air ekstrak

Uji ini untuk mengetahui berapa kadar air yang terdapat dalam ekstrak kental buah naga.

3) Uji kekentalan atau viskositas

Kekentalan ekstrak diukur dengan menggunakan viscometer Brookfield yang mempunyai prinsip kerja berdasarkan hambatan pemutar rotor oleh ekstrak yang diuji.

b. Analisis kandungan senyawa aktif

Setelah diekstraksi, ekstrak kental dilarutkan dengan etanol $70 \%$, kemudian divortex dan disentrifugasi. Dari proses ini akan diperoleh hasil larutan dan residu. Larutan ditotolkan pada alat uji KLT untuk melihat ada atau tidaknya senyawa alkaloid, flavonoid dan polifenol dari ekstrak buah naga. Uji KLT ini dilakukan untuk mengetahui apakah masih terkandung kandungan senyawa alkaoid dan flavonoid pada ekstrak buah naga (Hylocereus polyrhizus).

\section{Pembuatan amilum ubi jalar}

Pembuatan amilum ubi jalar dilakukan dengan cara umbi ubi jalar dikupas kulitnya, dicuci bersih, dipotong - potong kecil dan diblender hingga halus. Kemudian ampas ubi jalar disaring menggunakan kain sampai jernih dan diendapkan. Endapan yang diperoleh disaring dengan corong Buchner, dan dikeringkan. Endapan pati kering dihaluskan, diayak dengan mesh 40 dan diperoleh amilum ubi jalar.

\section{Pembuatan amilum ubi jalar pregelatinasi}

Pembuatan amilum ubi jalar pregelatinasi dilakukan dengan membuat suspensi amilum ubi jalar. Caranya yaitu dengan mencampur kan amilum ubi jalar dengan aquades (perbandingan 1:3) kemudian dipanaskan dengan menggunakan waterbath pada suhu $80^{\circ} \mathrm{C}$ sampai tebentuk suspensi. Suspensi yang diperoleh didinginkan dan disaring dengan corong Buchner, dikeringkan, dan dihancurkan atau dihaluskan kemudian diayak sehingga didapatkanlah amilum ubi jalar pregelatinasi.

\section{Rancangan Formula}

Formula tablet ekstrak buah naga dengan bahan penghancur amilum ubi jalar terpregelatinasi dapat dilihat pada tabel I. 
Tabel I. Formula Tablet ekstrak buah naga dengan amilum ubi jalar terpregelatinasi sebagai bahan pengancur

\begin{tabular}{lcccc}
\hline \multicolumn{1}{c}{ Bahan (mg) } & Formula I & Formula II & Formula III & Formula IV \\
\hline Ekstrak buah & 300 & 300 & 300 & 300 \\
naga & & & & \\
$\begin{array}{l}\text { Aerosil } \\
\text { Laktosa }\end{array}$ & 225 & 225 & 225 & 225 \\
$\begin{array}{l}\text { Mucilago amylli } \\
(10 \%)\end{array}$ & 17,28 & 47 & 47 & 47 \\
Amilum & 17,28 & 17,28 & 17,28 \\
pregelatinasi & 32,5 & 42,25 & 52 & 65 \\
$\begin{array}{l}\text { Mg stearat } \\
\text { Talkum }\end{array}$ & 1,3 & 1,3 & 1,3 & 1,3 \\
& 11,7 & 11,7 & 11,7 & 11,7 \\
\hline
\end{tabular}

\footnotetext{
Keterangan :

FI $\quad=$ tablet ekstrak buah naga dengan konsentrasi amilum ubi jalar pregelatinasi $5 \%$

FII = tablet ekstrak buah naga dengan konsentrasi amilum ubi jalar pregelatinasi $6,5 \%$

FIII = tablet ekstrak buah naga dengan konsentrasi amilum ubi jalar pregelatinasi $8 \%$

FIV = tablet ekstrak buah naga dengan konsentrasi amilum ubi jalar pregelatinasi $10 \%$
}

\section{Pembuatan Granul}

Pembuatan granul dilakukan dengan mencampurkan serbuk ekstrak kering buah naga dengan bahan pengisi laktosa, setengah bahan penghancur amilum ubi jalar pregelatinasi dan bahan pengikat mucilago amili $10 \%$, kemudian diayak dengan ayakan no. 16. Dikeringkan dalam almari pengering suhu $60^{\circ} \mathrm{C}$, setelah kering granul diayak lagi kemudian dilakukan uji sifat fisik granul.

\section{Pemeriksaan kadar air dan sifat alir granul}
a) Kadar Air
b) Waktu Alir
c) Sudut Diam
d) Pengetapan

\section{Pengempaan Tablet}

Granul yang telah diuji sifat fisiknya kemudian ditambahkan dengan setengah bahan penghancur yaitu Amilum ubi jalar pregelatinasi, bahan pelincir Mg stearat dan Talkum, kemudian dikempa dengan mesin kempa tablet single punch. Bobot masingmasing tablet sebesar $650 \mathrm{mg}$, dikempa dengan tekanan yang sama, kemudian dilakukan uji sifat fisik tablet.

\section{Pemeriksaan Sifat Fisik Tablet.}
a) Uji Keseragaman Bobot
b) Uji Kerapuhan tablet
c) Uji Kekerasan tablet
d) Uji waktu hancur tablet 


\section{HASIL DAN PEMBAHASAN}

\section{Determinasi Tanaman}

Determinasi bertujuan untuk memastikan dan membuktikan bahwa identitas tanaman yang dipergunakan dalam penelitian ini benar - benar tanaman buah naga (Hylocereus polyrhizus).

Hasil dari determinasi diperoleh rumus sebagai berikut :

1a- 2b- 3b- 4b- 6a (gol.3)- 34a- 35a- 86. Cactaceae

1a- 2b- 4b- 6a- 5. Hylocereus- Hylocereus polyrhizus.

Dari hasil rumus determinasi diatas dapat dipastikan bahwa buah yang digunakan dalam penelitian ini merupakan buah naga (Hylocereus polyrhizus).

\section{Hasil Ekstraksi Buah Naga}

Hasil ekstraksi didapatkan ekstrak kental yang berwarna merah keunguan. Rendemen yang dihasilkan dalam penelitian ini adalah $62,48 \%$ artinya dalam $1250 \mathrm{~g}$ serbuk kering buah naga mengandung $62,48 \%$ ekstrak. Rendemen berguna sebagai perbandingan perolehan ekstrak yang didapat, sehingga kita memperoleh data kebutuhan sampel.

\section{Hasil Uji Sifat Fisik Ekstrak Buah Naga}

Uji sifat fisik ekstrak dilakukan untuk mendapatkan kriteria -kriteria fisik dari ekstrak buah naga yang akan diformulasikan menjadi bentuk sediaan tablet.

\section{Pemeriksaan Karakteristik ekstrak buah naga}

Hasil pemeriksaan karakteristik ekstrak buah naga terdapat dalam tabel 2 menunjukkan bahwa ekstrak buah naga yang diperoleh dari hasil ekstraksi mempunyai bentuk berupa ekstrak kental yang berwarna merah keunguan, kemudian mempunyai bau yang khas dan rasa pahit. Kandungan air dalam suatu sediaan yang berasal dari tumbuhan juga sangat perlu diperhatikan karena kandungan air yang terlalu tinggi dapat menyebabkan kerusakan pada sediaan tersebut. Hasil dari uji kadar air diperoleh bahwa kandungan rata - rata kandungan air dari ekstrak buah naga adalah 16,99\%. Hasil ini sudah memenuhi syarat karena syarat kadar air untuk ekstrak yang akan dibuat sediaan tablet adalah kurang dari $30 \%$.

Untuk melihat kekentalan dari ekstrak buah naga, digunakan rotor no S64 dengan kecepatan 100 rpm dihasilkan kekentalan rata - rata 4590,20 cP. Kekentalan ekstrak akan berpengaruh pada proses homogenitas. Semakin kental ekstrak yang digunakan maka akan semakin kuat ikatan antar partikelnya sehingga akan menyebabkan waktu hancur tablet menjadi lebih lama.

Tabel II. Data Hasil Uji Karakteristik Ekstrak Buah Naga

\begin{tabular}{lc}
\hline \multicolumn{1}{c}{ Parameter } & Deskripsi \\
\hline Bentuk & Ekstrak kental \\
Warna & Merah keunguan \\
Bau & Khas \\
Rasa & Pahit \\
Kadar Air & $16,99 \%$ \\
Kekentalan & $4590,20 \mathrm{cP}$ \\
\hline
\end{tabular}

\section{Analisis kandungan senyawa aktif}

Uji kandungan senyawa ekstrak buah naga bertujuan untuk mengetahui dan memastikan apakah didalam ekstrak buah naga ini terkandung senyawa Alkaloid, Flavonoid dan senyawa fenolik. Kandungan kimia ekstrak metanolik buah naga 
menggunakan metode Kromatografi Lapis Tipis (KLT). Dari uji yang dilakukan diketahui bahwa dalam ekstrak buah naga terdapat kandungan alkaloid, flavonoid, dan polifenol.

a. Alkaloid

Hasil KLT (gambar 1) dari ekstrak buah naga akan dibandingkan dengan pembanding atau komparator. Komparator yang digunakan adalah Quinine. Dari hasil diperoleh warna spot alkaloid di visible berwarna kuning dengan $R f$ alkaloid terdeteksi 0,14. Hasil ini menunjukkan bahwa ekstrak (+) terdapat senyawa alkaloid.

b. Flavonoid

Deteksi flavonoid tanpa perlakuan kimia dapat dilihat dengan sinar UV $365 \mathrm{~nm}$ dimana senyawa flavonoid akan berflourosensi kuning gelap, biru atau hijau tergantung pada struktur kimia yang dapat diintensifkan dengan pereaksi semprot yang bermacam-macam. Hasil uji KLT flavonoid dapat dilihat pada gambar 2.

UV $254 \mathrm{~nm}$

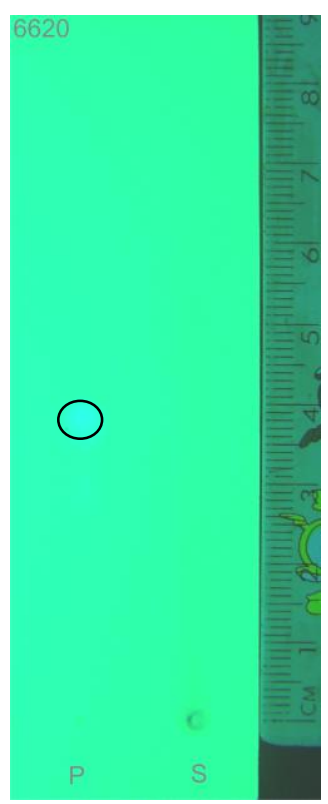

Keterangan

Fase diam

Fase gerak

Pereaksi

$\mathrm{P}$

S
UV $365 \mathrm{~nm}$

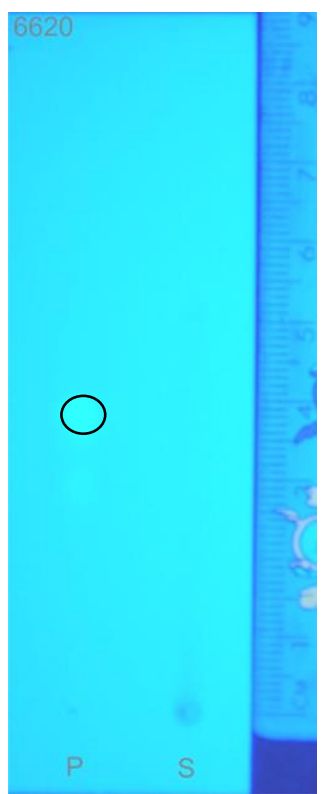

: silika gel $\mathrm{F}_{254}$

: metanol : amoniak $(100: 1,5)$

: dragendorff

: bercak pembanding Quinine

: sampel ekstrak buah naga

Gambar 1. Hasil uji kualitatif Alkaloid pada ekstrak buah naga dengan menggunakan metode Kromatografi Lapis Tipis (KLT). 


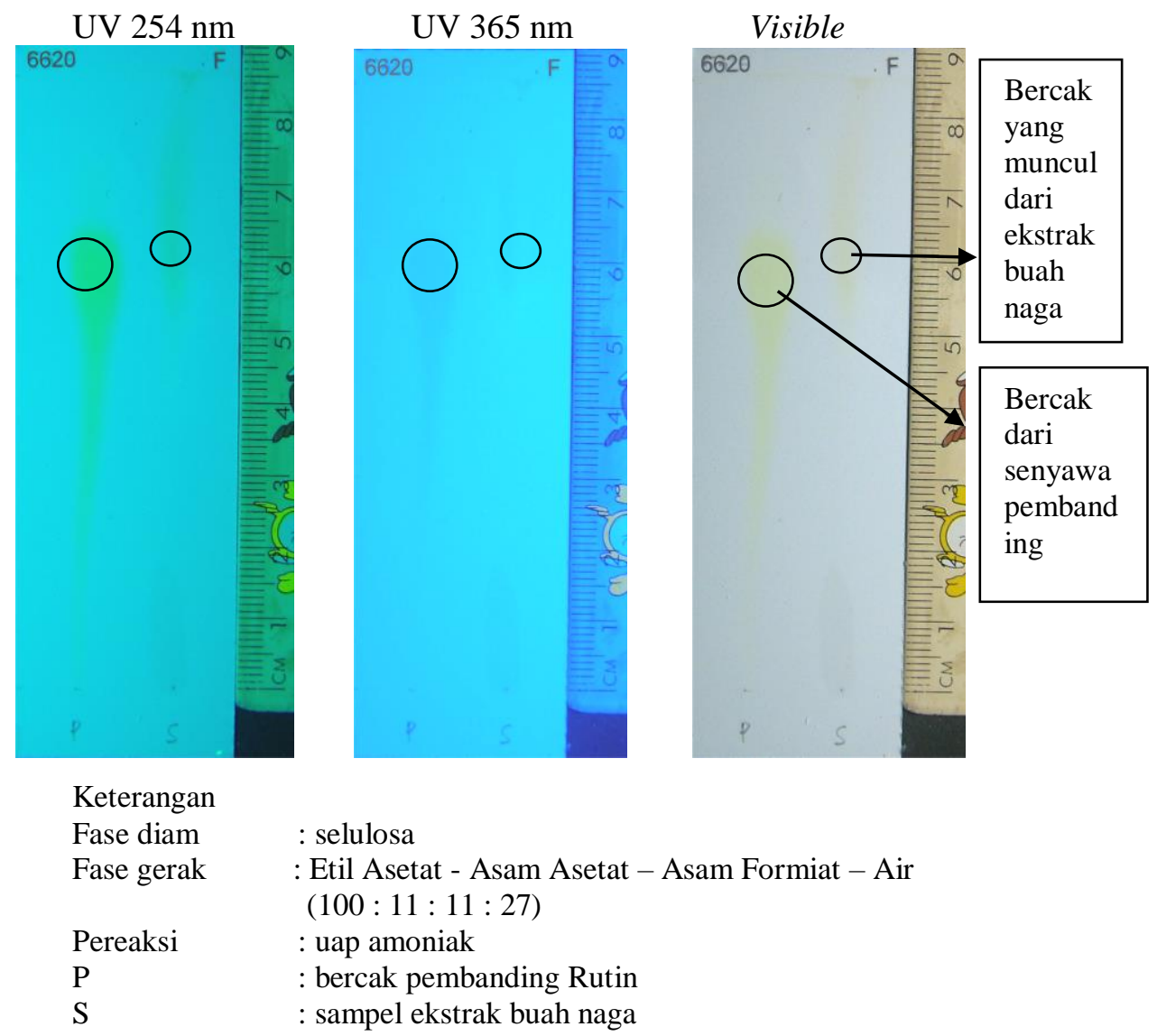

\section{Gambar 2. Hasil uji kualitatif Flavonoid pada ekstrak buah naga dengan menggunakan Kromatografi Lapis Tipis (KLT).}

Pada uji flavonoid fase diam yang digunakan adalah selulosa. Digunakan selulosa karena jika menggunakan silika maka akan terjadi rekasi antara gugus $\mathrm{OH}$ pada silanol silika gel dengan gugus $\mathrm{OH}$ pada flavonoid sehingga akan mengganggu proses pemisahan senyawa. Hasil uji KLT dari ekstrak buah naga akan dibandingkan dengan pembanding atau komparator. Komparator yang digunakan adalah Rutin. Dari hasil diperoleh warna spot alkaloid di visible berwarna kuning pada daerah visibel dengan $R f$ flavonoid terdeteksi 0,74 . Hasil ini menunjukan bahwa ekstrak (+) terdapat senyawa flavonoid.

\section{c. Senyawa fenolik}

Senyawa fenolik merupakan senyawa yang dapat berfungsi sebagai senyawa anti oksidan. Uji kandungan senyawa fenolik pada ekstrak buah naga (Hylocereus polyrhizus) digunakan fase diam silika gel $60 \mathrm{~F}_{254}$ dan fase gerak yang digunakan yaitu metanol : asam formiat $10 \%=95: 5$. 
UV $254 \mathrm{~nm}$

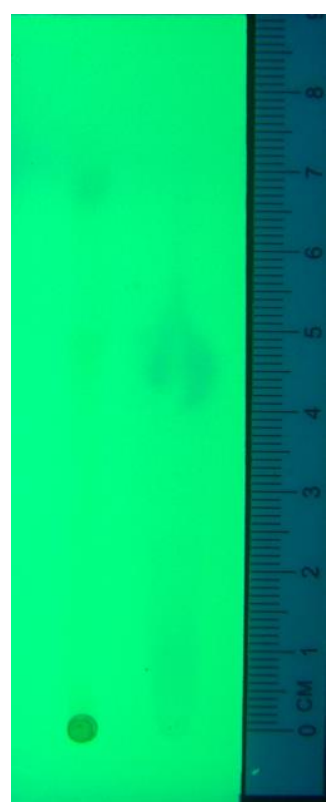

Keterangan

Fase diam

$\mathrm{P}$

Fase gerak

$\mathrm{S}$

Pereaksi
UV $365 \mathrm{~nm}$

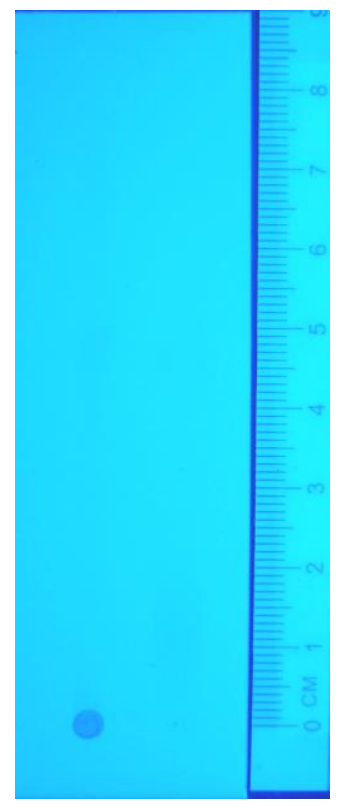

: silika gel $60 \mathrm{~F}_{254}$

: bercak pembanding fenol (E.Merck)

: metanol - asam formiat $10 \%(95: 5)$

: sampel ekstrak buah naga

: ferri chloride

\section{Gambar 3. Hasil uji kualitatif senyawa fenolik pada ekstrak buah naga dengan menggunakan Kromatografi Lapis Tipis (KLT).}

Hasil uji KLT (gambar 3) dari ekstrak buah naga dibandingkan dengan komparator atau pembanding fenol (E.Merck). Dari hasil uji diperoleh warna spot senyawa fenolik di visible berwarna biri-kelabu dan $R f$ senyawa fenolik terdeteksi 0,54. Hasil ini menunjukan bahwa ekstrak (+) terdapat senyawa fenolik.

\section{Hasil Pembuatan Amilum Ubi Jalar Pregelatinasi}

Penelitian ini menggunakan ubi jalar yang dibudidayakan di daerah Muntilan, Magelang, Jawa tengah. Ubi jalar yang digunakan adalah sebanyak $3 \mathrm{~kg}$ sedangkan amilum yang diperoleh adalah $433 \mathrm{~g}$. Dari penelitian tersebut diketahui bahwa amilum ubi jalar pregelatinasi dengan suhu pemanasan $80^{\circ} \mathrm{C}$ mempunyai kemampuan sebagai bahan penghancur yaitu ditunjukan dengan kapasitas pengembangan (capacity swelling) sebesar $166,67 \%$ dan hasil ini lebih besar dibandingkan dengan amprotab yang hanya sebesar $25 \%$.

\section{1) Pemeriksaan Sifat Alir dan Kadar Air Granul}

Pemeriksaan sifat alir dan kadar air granul meliputi: pengetapan, waktu alir, sudut diam, dan kadar air granul. Dari data penelitian diperoleh data sifat fisik granul yang disajikan dalam tabel III. 
Tabel III. Hasil Uji Sifat Alir dan Kadar Air Granul Tablet Ekstrak Buah Naga

\begin{tabular}{lllll}
\hline Sifat Fisik & Formula I & Formula II & Formula III & Formula IV \\
\hline Pengetapan (\%) & $14 \pm 0,71$ & $11,40 \pm 1,34$ & $12,60 \pm 1,52$ & $14,20 \pm 1,09$ \\
Waktu alir & $7,02 \pm 0,29$ & $6,24 \pm 0,15$ & $7,10 \pm 0,07$ & $7,72 \pm 0,08$ \\
(detik) & & & & \\
Sudut diam $\left({ }^{(}\right)$ & $31,46 \pm 0,35$ & $29,69 \pm 1,31$ & $29,50 \pm 0,99$ & $29,51 \pm 0,58$ \\
Kadar air $(\%)$ & $3,69 \pm 0,38$ & $4,26 \pm 0,89$ & $4,59 \pm 0,33$ & $3,53 \pm 0,26$ \\
\hline
\end{tabular}

Keterangan

Formula I

Konsentrasi amilum pregelatinasi ubi jalar 6,5

Formula IV : Konsentrasi amilum pregelatinasi ubi jalar $10 \%$

a. Uji pengetapan

Evaluasi ini bertujuan untuk memperoleh massa granul dengan porositas yang kecil sehingga kompaktibilitas dan kompresibilitas menjadi lebih baik. Suatu partikel dari granul atau serbuk bila dikempa akan mengalami deformasi. Deformasi ini merupakan salah satu aksi mekanik dari suatu partikel, dan keadaan ini akan berpengaruh bagi sifat fisik tablet, mudah atau tidaknya suatu serbuk atau granul dikempa tergantung dari kompresibilitas dan kompaktibilitasnya. Uji pengetapan ditunjukan dengan harga indeks pengetapan ( $T \%)$. Granul dengan indeks pengetapan kurang dari $20 \%$ mempunyai sifat alir yang baik (Sulaiman, 2007).

Berdasarkan hasil uji yang diperoleh diketahui bahwa granul atau serbuk dari empat formula yang digunakan mempunyai sifat alir yang baik. Hal ini dapat diketahui dari indeks pengetapan masing - masing formula yang memiliki indeks pengetapan kurang dari $20 \%$. Penambah amilum pregelatinasi akan memperkecil indeks pengetapan akan tetapi penambahan lebih lanjut justru membuat indeks pengetapan menjadi besar.

Indeks pengetapan dipengaruhi oleh beberapa faktor yaitu bentuk granul, kerapatan dan ukuran granul. Partikel dengan ukuran yang lebih kecil akan membentuk masa dengan ukuran yang lebih besar, akibat pengurangan rongga rongga antar partikel (Russell, 1990). Selain itu, bentuk partikel juga mempengaruhi densitas bulk dimana partikel-partikel dengan bentuk irregular cenderung memiliki porositas besar diakibatkan rongga-rongga antar partikel yang terisi oleh udara sehingga densitas bulk lebih kecil (Gorgon et al., 1990).

b. Uji waktu alir

Waktu alir merupakan salah satu uji yang digunakan untuk mengetahui sifat alir dari serbuk atau granul. Waktu alir yang baik untuk granul adalah kurang dari 10 g/detik, dengan nilai tersebut granul dikatakan memiliki sifat alir yg baik dan sudah siap untuk dikempa (Sulaiman, 2007).

Dari hasil pada tabel 3 diketahui bahwa pada masing - masing formula secara umum sudah mempunyai waktu alir yang baik dan sesuai ketentuan yaitu waktu alirnya kurang dari $10 \mathrm{~g} /$ detik. Penambahan konsentrasi amilum ubi jalar pregelatinasi akan membuat waktu alirnya semakin cepat, tetapi penambahan lebih lanjut justru waktu alirnya semakin menurun. Hal ini ditunjukan pada tabel bahwa pada konsentrasi 5\% waktu alirnya 7,02 detik dan pada konsentrasi $6,5 \%$ waktu alirnya semakin cepat yaitu 6,24 detik, tetapi pada konsentrasi $8 \%$ waktu alirnya menjadi 7,1 detik.

Kemampuan mengalir dari granul atau serbuk dipengaruhi oleh beberapa hal diantaranya: bentuk partikel, ukuran partikel, kekasaran (sifat berkerut, dimensi fraktal) dari partikel (Sastrohamidjojo, 2001). Bila partikel terlalu halus maka granul 
tersebut tidak akan dapat mengelir dengan baik atau berhenti. Partikel dengan bentuk sferis (bulat) akan memperkecil luas permukaan partikel yang bersinggungan dengan granul lainnya sehingga akan menurunkan daya kohesi dan adesi dari serbuk atau granul yang dapat membuat granul akan mudah mengalir (Gorgon et al., 1990).

c. Uji sudut diam

Parameter sudut diam ini tergantung dari gesekan dan daya kohesi pada serbuk atau granul. Secara umum semakin tinggi sudut diam maka semakin buruk sifat alir dari serbuk (Birudaraj, 2005). Faktor - faktor yang mempengaruhi sudut diam diantaranya ukuran partikel, bentuk, kelembaban granul (Gorgon et al., 1990). Menurut USP 30 sudut diam $25^{0}-35^{\circ}$ menunjukan sifat alir yang baik (Anonim, 2007).

Dari hasil uji sudut diam diperoleh bahwa kempat formula mempunyai range sudut diam antara 29,50-31,46 maka dapat disimpulkan bahwa pada formula I, II, III ,dan IV mempunyai sifat alir yang sangat baik. Hal tersebut menunjukan bahwa penambahan amilum ubi jalar pregelatinasi dapat menurunkan sudut diam sehingga dapat meningkatkan sifat alir dari granul.

Sifat alir yang baik pada granul akan mempengaruhi pada proses pencetakan tablet, yaitu dapat mempengaruhi tingkat keseragaman ukuran atau masa dari tablet yang dihasilkan. Granul yang memiliki sifat alir yang baik, akan dengan mudah mengalir ke dalam ruang kompresi sehingga akan didapatkan tablet yang memiliki ukuran atau massa yang seragam.

\section{2) Pemeriksaan Sifat Fisik Tablet Ekstrak Buah Naga}

Setelah granul diperoleh sifat fisiknya dan memenuhi syarat, granul kemudian dikempa dengan menggunakan mesin pengempa tablet (single punch) dengan pengaturan tekan dan bobot yang diinginkan.

Tabel IV. Hasil Pemeriksaan Sifat Fisik Tablet Ekstrak Buah Naga

\begin{tabular}{lllll}
\hline Sifat Fisik & Formula I & Formula II & Fornula III & Formula IV \\
\hline $\begin{array}{l}\text { Bobot tablet }(\mathrm{mm}) \\
\% \text { CV }\end{array}$ & $656,55 \pm 12,42$ & $651,11 \pm 10,73$ & $660,15 \pm 11,38$ & $655,70 \pm 12,61$ \\
Tebal tablet $(\mathrm{mm})$ & 3,89 & 1,65 & 1,72 & 1,92 \\
$\begin{array}{l}\text { Diameter tablet } \\
(\mathrm{mm})\end{array}$ & $13,10 \pm 0,03$ & $3,50 \pm 0,08$ & $3,58 \pm 0,02$ & $3,49 \pm 0,11$ \\
$\begin{array}{l}\text { Kekerasan }(\mathrm{Kg}) \\
\text { Kerapuhan }(\%)\end{array}$ & $13,08 \pm 0,02$ & $13,08 \pm 0,02$ & $13,10 \pm 0,04$ \\
$\begin{array}{l}\text { Waktu hancur } \\
\text { (menit) }\end{array}$ & $0,29 \pm 0,25$ & $0,58 \pm 0,54$ & $0,46 \pm 0,46$ & $1,18 \pm 0,09$ \\
& $41,69 \pm 2,19$ & $36,43 \pm 1,75$ & $35,15 \pm 1,55$ & $32,03 \pm 0,82$ \\
\hline
\end{tabular}

Keterangan

Formula I : Konsentrasi amilum pregelatinasi ubi jalar $5 \%$

Formula II : Konsentrasi amilum pregelatinasi ubi jalar 6,5\%

Formula III : Konsentrasi amilum pregelatinasi ubi jalar $8 \%$

Formula IV : Konsentrasi amilum pregelatinasi ubi jalar $10 \%$

a. Uji organoleptik

Identifikasi ini juga merupakan identifikasi awal terhadap homogenitas serta stabilitas sediaan (Sulaiman, 2007). Warna tablet harus seragam baik secara individu (dalam satu tablet) maupun antar tablet. Tablet ekstrak buah naga menunjukkan keempat formula tidak ada retakan, bebas dari serpihan, warna tablet merah muda, tetapi ada noda bintik - biktik putih. 
b. Keseragaman bobot

Keseragaman bobot sangat erat hubungannya dengan keseragaman kadar zat aktif yang terkandung dalam tiap tablet. Dari hasil uji diperoleh bahwa dari keempat formula penyimpangan bobotnya tidak ada yang melebihi $5 \%$, sehingga dapat dikatakan bahwa bobot tablet seragam. Parameter lain untuk menilai keseragaman bobot adalah harga koefisien variasi (CV) yang digunakan untuk menentukan apakah berat tablet tersebut konstan atau tidak, tablet yang baik mempunyai harga $\mathrm{CV} \leq 5 \%$. Dari data tabel IV menunjukkan bahwa harga CV kelima formula memenuhi syarat keseragaman bobot.

c. Keseragaman ukuran

Pada kondisi pengempaan yang konstan, ketebalan tablet dapat bervariasi tergantung pada pengisian die, distribusi ukuran partikel dan kekompakan partikel ketika dikompres. Variasi ketebalan yang baik kurang lebih 5\% dari nilai rata ratanya, atau perbedaan ketebalan tablet harus tidak dapat dibedakan hanya melihat atau mengukur (Sulaiman, 2007).

Dari hasil uji keseragaman ukuran diperoleh bahwa variasi ketebalan tablet tidak ada yang melebihi 5\% (tabel IV). Hal ini menunjukan bahwa tablet ekstrak buah naga ini mempunyai ukuran yang seragam. Keseragaman tablet ini diperoleh karena granul mempunyai kekompakan partikel yang bagus sehingga ketika dikempa partikel - partikel granul akan saling berikatan dan dihasilkanlah tablet yang mempunyai ukuran seragam.

d. Uji kekerasan

Kekerasan tablet harus menjadi pertimbangan untuk merumuskan pengembangan formulasi, karena dapat memiliki pengaruh yg signifikan terhadap parameter kualitas tablet seperti sifat dinsintegrasi dan disolusi (Gorgon et al., 1990). Tablet umumnya dikatakan baik jika mempunyai kekerasan antara $4-10 \mathrm{~kg}$ (Sulaiman, 2007).

Dari hasil uji diketahui bahwa kekerasan pada formula I, II, III, dan IV mempunyai kekerasan yang sudah memenuhi standar yaitu kekerasan yang diperoleh antara 6,23 - 7,97 Kg. Dari penelitian dapat dilihat bahwa semakin tinggi konsentrasi bahan penghancur yaitu amilum ubi jalar pregelatinasi yang diberikan serta merata akan menyebabkan semakin kecil kekerasan tabletnya. Sifat kekerasan tablet sangat mempengaruhi sifat fisik tablet lainnya yaitu kerapuhan dan waktu hancur tablet. Penggunaan magnesium stearat dalam formulasi juga mempengaruhi kekerasan tablet. Magnesium stearat mampu membentuk film pada eksipien tablet selama mixing,dan mengarah pada memperlama waktu pelepasan obat, penurunan kekerasan,dan mempercepat waktu disintegrasi tablet (Schmidt, 2007).

e. Uji kerapuhan

Kerapuhan adalah ukuran dari kemampuan tablet untuk menahan goncangan dan abrasi tanpa runtuh selama proses manufaktur, pengemasan, pengiriman, dan penggunaan konsumen (Gorgon et al., 1990). Dari hasil penelitian tersebut menunjukan bahwa pada formula I, II dan III lolos uji kerapuhan karena mempunyai kerapuhan kurang dari $1 \%$, sedangkan pada formula IV tidak lolos uji kerapuhan karena kerapuhannya lebih dari $1 \%$. Semakin tinggi konsentrasi amilum ubi jalar pregelatinasi memuat kekerasan dari tablet menurun. Hal ini terjadi karena amilum ubi jalar pregelatinasi sebagai bahan penghancur dengan kemampuan sangat baik mengembangnya yang cukup besar dengan tetap mempertahankan keutuhannya. Pengembangan tersebut dapat memberikan dorongan ke daerah sekitarnya sehingga membantu proses pecahnya tablet

Kerapuhan akan menurun dengan adanya peningkatan jumlah pengikat. Sifat kohesif dari bahan pengikat juga mempengaruhi kerapuhan dari tablet (Shargel dan 
$\mathrm{Yu}$, 2007). Kerapuhan tablet juga mungkin dipengaruhi oleh kadar air granul tablet pada tablet yang sudah selesai / jadi. Granulasi yang sangat kering yang hanya mengandung sedikit kadar air akan mengakibatkan tablet lebih rapuh dari granulasi yang mengandung kelembaban $2-4 \%$ (Gorgon et al., 1990).

f. Uji waktu hancur

Uji disintegrasi memungkinkan pengukuran untuk presisi dari fragmen, butiran, atau agregat dari sediaan tablet, tetapi tidak memberikan informasi tentang laju disolusi zat aktif (Shargel dan Yu, 2007). Tablet dikatakan mempunyai waktu hancur yang baik jika mempunyai waktu hancur kurang dari 15 menit (Sulaiman, 2007).

Hasil uji waktu hancur terhadap keempat formulasi tablet menunjukan bahwa waktu hancurnya tidak memenuhi persyaratan karena mempunyai waktu hancur lebih dari 15 menit. Hasil ini berbeda dengan penelitian yang dilakukan oleh Dharma yaitu bahwa amilum ubi jalar dapat digunakan sebagai bahan penghancur pada tablet paracetamol (Dharma, 2011). Salah satu faktor yang menyebabkan waktu hancur pada tablet ekstrak buah naga ini lama, diantaranya karena zat aktif yang digunakan dalam bentuk ekstrak yang berasal dari bahan alam dengan menggunakan pelarut metanol $80 \%$.

Peningkatan konsentrasi amilum pregelatiasi mengakibatkan waktu hancur dari tablet semakin cepat karena amilum pregelatinasi dapat berfungsi sebagai disintegran karena amilum akan mengembang bila terkena/ terpapar air (swelling). Amilosa yang bertanggung jawab dalam sifat disintegrasi dari amilum. Mekanisme yang kedua dari aksi amilum pada tablet adalah aksi kapilaritas daripada swelling. Sedangkan mekanisme yang ketiga adalah kekuatan tolakan partikel - partikel antara konstituen tablet ketika kontak dengan air dan sifat hidrofilik dari amilum (Newman, 2007).

Ukuran partikel yang lebih kecil akan membuat luas permukaan juga akan meningkat, hal ini akan mengakibatkan penetrasi air ke dalam partikel juga akan meningkat dan meningkatkan laju disolusi. Obat yang sukar larut diperlukan suatu disintegran atau bahan penghancur ke dalam formulasi untuk memastikan disintegrasi cepat dari tablet dan pelepasan partikel (Shargel dan Yu, 2007). Kemampuan disintegran untuk menarik air ke dalam jaringan berpori pada tablet penting untuk efektivitas disintegrasi (Augsburger,2007). Meskipun penetrasi air adalah langkah awal untuk disintegrasi tetapi mekanisme swelling yang paling banyak diterima pada proses disintegrasi.

Air masuk ke dalam tablet melalui hidrofilik pori - pori dan jaringan pati berkesinambungan yang dapat menyampaikan air dari satu partikel ke partikel lainnya. Air kemudian menembus antara butir pati karena afinitas pati dengan permukaan, sehingga memecah ikatan hidrogen (Augsburger,2007).

\section{KESIMPULAN}

Amilum ubi jalar pregelatinasi mempengaruhi kekerasan, kerapuhan dan waktu hancur dari tablet ekstrak buah naga (Hylocereus polyrhizus) yang dibuat, semakin tinggi konsentrasinya akan membuat kekerasan tablet menurun, kerapuhan menjadi semakin besar dan waktu hancur tablet semakin cepat.

\section{DAFTAR PUSTAKA}

Anonim, 2005, Taiwan Food Industry Develop \& Research Authorities. dalam Trubus 456 November 2007 XXXVIII

Anonim, 2007. USP30-NF25 Pharmacopea The Standar of Quality. Port City Press, Baltimore, $644-645$. 
Augsburger, Larry L., Brzeczko, Albert W., Shah, Umang., dan Hahm, Huijeong, 2007, Super Disintegrant: Characterization and Function, In Swarbick, James., (Ed.), Encyclopedia of Pharmaceutical Technology,Third Edition, Vol 1, Informa Healthcare USA, Inc, New York, 3556 - 3557, 3560, 3562.

Birudaraj, Raj., Goskonda, Sanjay., dan Pande, Poonam G., 2005, Granulation Characterization, In Swarbick, James., (Ed.), Handbook of Pharmaceutical Granulation Technology, Second edition, Taylor \& Francis Group, Boca Raton, 528,530 .

Dharma, Wan S.T., 2010, Uji Stabilitas Fisika dan Kimia Tablet Parasetamol dengan Amilum Ubi Jalar Sebagai Bahan penghancur, Skripsi, Jurusan Farmasi Fakultas Matematika dan Ilmu Pengetahuan Alam, Universitas Islam Indonesia, Yogyakarta.

Gordon, R.E., Rosanke, TW., Fonner, DE., Anderson, NR dan Banker, GS, 1990, Granulation Technology and Tablet Characterization, In Liberman H.A., Lachman, L., dan Schwartz, J.B., (Eds.), Pharmaceutical Dosage Form : Tablet, Second Edition, Vol 2, Marcel Dekker Icn, New York, 35, 291-292, 327-330.

Jaafar, R.A., et al., 2009, Proximate Analysis of Dragon Fruit (Hylocereus polyrhizus), Malaysia. American Journal of Applied Sciences 6 (7): 1341 - 1346.

Lanz, Russell J., 1990, Size Reduction, In Liberman H.A., Lachman, L., dan Schwartz, J.B., (Eds.), Pharmaceutical Dosage Form : Tablet, Second Edition, Vol 2, Marcel Dekker Icn, New York, 162-167.

Li-chen Wu, Hsiu-Wen Hsu, Yun-Chen Chen, Chih-Chung Chiu, Yu-In Lin, and Ja-an Annie., 2006, Antioxidant and antiproliferative activities of red pitaya, Food Chemistry Volume 95, Issue 2, March pages 319- 327.

Newman, Ann W., Mueller, Ronald L., Vites, Imre M., dan Kiesnowski Chris C., 2007, Starches and Starche Derivatives In Swarbick, James., (Ed.), Encyclopedia of Pharmaceutical Technology, Third Edition, Vol 1, Informa Healthcare USA, Inc, New York, 3480.

Ni'ma, Adibah., 2010, Karakteristik Fisikomekanik Amilum Ubi Jalar (Ipomoea batatas L.) Pregelatinasi Sebagai Bahan Tambahan dalam Formulasi Tablet, Skripsi, Jurusan Farmasi Fakultas Matematika dan Ilmu Pengetahuan Alam, Universitas Islam Indonesia, Yogyakarta

Nurliyana, R., Syed Zahir, I., Mustapha Suleiman, K., 'Aisyah, M.R., and Kamarul Rahim, K., 2010, Antioxidant study of pulps and peelsof dragon fruits: a comparative study, International Food Research Journal 17: 367 - 375.

Rebecca, O.P.S., Boyce, A.N., dan Chandran, S., 2010, Pigmen Identification and Antioxidant properties of Red Dragon Fruit (Hylocereus polyrhizus), Africant Journal of Biotechnology vol. 9(10) : 1450 - 1454.

Sastrohamidjojo, H. 2001. Kromatografi, Edisi II, Liberty, Yogyakarta, 26-34.

Schmidt, Peter C., 2007, Secondary Electron Microscopy in Pharmaceutical Technology, In Swarbick, James., (Ed.), Encyclopedia of Pharmaceutical Technology,Third Edition, Vol 1, Informa Healthcare USA, Inc, New York, 3231.

Shargel, Leon., dan Yu, Andrew B.C., 2007, Biopharmceutics, In Swarbick, James., (Ed.), Encyclopedia of Pharmaceutical Technology,Third Edition, Vol 1, Informa Healthcare USA, Inc, New York, 218-219.

Sulaiman, T.N. 2007. Teknologi dan Formulasi Sediaan Tablet. Pustaka Laboratorium Tegnologi Farmasi Fakultas Farmasi Universitas Gajah Mada, Yogyakarta, 49 - 176. 